\title{
Differential Increase in Taurine Levels by Low-Dose Ethanol in the Dorsal and Ventral Striatum Revealed by Microdialysis With On-Line Capillary Electrophoresis
}

\author{
A. Smith, C. J. Watson, K. J. Frantz, B. Eppler, R. T. Kennedy, and J. Peris
}

\begin{abstract}
Ethanol increases taurine efflux in the nucleus accumbens or ventral striatum (VS), a dopaminergic terminal region involved in positive reinforcement. However, this has been found only at ethanol doses above $1 \mathrm{~g} / \mathrm{kg}$ intraperitoneally, which is higher than what most rats will self-administer. We used a sensitive on-line assay of microdialysate content to test whether lower doses of ethanol selectively increase taurine efflux in VS as opposed to other dopaminergic regions not involved in reinforcement (e.g., dorsal striatum; DS). Adult male rats with microdialysis probes in VS or DS were injected with ethanol $(0,0.5,1$, and $2 \mathrm{~g} / \mathrm{kg}$ intraperitoneally), and the amino acid content of the dialysate was measured every $11 \mathrm{sec}$ using capillary electrophoresis and laser-induced fluorescence detection. In VS, $0.5 \mathrm{~g} / \mathrm{kg}$ ethanol significantly increased taurine levels by $20 \%$ for $10 \mathrm{~min}$. A similar increase was seen after $1 \mathrm{~g} / \mathrm{kg}$ ethanol, which lasted for about $20 \mathrm{~min}$ after injection. A two-phased taurine efflux was observed with the $2.0 \mathrm{~g} / \mathrm{kg}$ dose, where taurine was increased by 2 -fold after $5 \mathrm{~min}$ but it remained elevated by $30 \%$ for at least $60 \mathrm{~min}$. In contrast, DS exhibited much smaller dose-related increases in taurine. Glycine, glutamate, serine, and $\gamma$-aminobutyric acid were not systematically affected by lower doses of ethanol; however, $2 \mathrm{~g} / \mathrm{kg}$ slowly decreased these amino acids in both brain regions during the hour after injection. These data implicate a possible role of taurine in the mechanism of action of ethanol in the VS. The high sensitivity and time resolution afforded by capillary electrophoresis and laser-induced fluorescence detection will be useful for detecting subtle changes of neuronally active amino acids levels due to low doses of ethanol.
\end{abstract}

Key Words: Ethanol, Taurine, Ventral Striatum, On-Line Microdialysis, Capillary Electrophoresis, Amino Acids.

$\mathbf{T}$ HE ABILITY OF ethanol to increase dopamine signaling in the nucleus accumbens or ventral striatum (VS) is thought to be one of the possible neurobiological mechanisms for the positive reinforcement caused by ethanol consumption (Brodie et al., 1990; Brodie and Appel, 1998; Nurmi et al., 1998; Yim et al., 1998: Yoshimoto et al., 1991). Support for this possibility is that disruption of ethanol-induced dopamine efflux via a number of different approaches reduces alcohol self-administration (El-Ghundi et al., 1998; Gonzales and Weiss, 1998; Phillips et al., 1998).

From the Department of Pharmacodynamics (AS, BE, JP), University of Florida, Gainesville, Florida; Department of Chemistry (CJW, RTK), University of Michigan, Ann Arbor, Michigan; and the Scripps Research Institute (KJF), La Jolla, California.

Received for publication January 26, 2004; accepted May 4, 2004.

Supported by Grants AA07561 and NS 38476 from the Public Health Service.

A. Smith and C.J. Watson contributed equally to this manuscript.

Reprint requests: Joanna Peris, PhD, Department of Pharmacodynamics, Box 100487, University of Florida, Gainesville FL 32610; Fax: 352-392-9187; E-mail:Peris@cop.ufl.edu.

Copyright () 2004 by the Research Society on Alcoholism.

DOI: 10.1097/01.ALC.0000131979.78003.34
Acamprosate (a calcium homolog of the naturally-occurring amino acid, taurine) and homotaurine (a taurine precursor) are drugs that decrease both ethanol self-administration and ethanol-induced dopamine efflux (Olive et al., 2002); however, the mechanism for this effect is not known.

Ethanol affects many different neural systems such as activating inhibitory $\gamma$-aminobutyric (GABA) receptors (Allan and Harris, 1987; Harris, 1999; Proctor et al., 2003) and inhibiting excitatory glutamate receptors (Fitzgerald and Nestler, 1995; Lovinger et al., 1989). Similar to ethanol, taurine has been shown to positively modulate GABA receptor function (Bureau and Olsen, 1991; Del Olmo et al., 2000; Liljequist, 1993; Quinn and Harris, 1995) and glycine receptor function (Han et al., 2001; Mori et al., 2002; Sergeeva and Haas, 2001). Changes in the levels of neurotransmitters affected by ethanol could lead to the pathologic state of alcoholism (Nevo and Hamon, 1995; Tsai, 1998). In the nucleus accumbens, acute ethanol does not alter GABA efflux (Dahchour et al., 1994, 1996; De Witte et al., 1994; Heidbreder and De Witte, 1993; Moghaddam and Bolinao, 1994), but taurine levels are increased in a dose-dependent manner by ethanol (Dahchour et al., 
1994), and this effect is enhanced by repeated ethanol exposure (Dahchour et al., 1994, 1996; Dahchour and De Witte, 2000a). In contrast, acute low doses of ethanol have been shown by some to increase glutamate efflux, whereas higher doses decrease glutamate efflux (Dahchour et al., 1994, 1996; De Witte et al., 1994; Heidbreder and De Witte, 1993; Moghaddam and Bolinao, 1994). Interestingly, glutamate receptor agonists can also increase taurine release (Lehmann et al., 1985; Magnusson et al., 1991; Oja and Saransaari, 2000; Saransaari and Oja, 2000). Taurine alters the reinforcing properties of ethanol (Aragon and Amit, 1993; Quertemont et al., 1998), and rats genetically selected for differences in ethanol self-administration exhibit alterations in both ethanol-induced taurine and dopamine efflux in the nucleus accumbens (Dahchour et al., 2000; Piepponen et al., 2002; Quertemont et al., 2002).

Although this evidence is suggestive for a role of taurine in ethanol reinforcement, significant gaps exist in our knowledge of how this can occur. Not all genetically selected strains exhibit differential ethanol-induced dopamine efflux (Kiianmaa et al., 1995; Yoshimoto et al., 1992) nor have they all been tested for alterations in taurine efflux. Also, self-administering animals normally ingest around $0.5 \mathrm{~g} / \mathrm{kg}$ of ethanol, yet taurine levels have not been demonstrated to be altered by such low doses. In addition, the temporal pattern of taurine efflux relative to ethanol administration has not been sufficiently characterized to determine if it could play a primary role in mediating the reinforcing effects of ethanol. Finally, the selectivity of taurine changes has not been directly compared across brain regions. If ethanol affects taurine in a similar fashion throughout the brain, a specific neuronal role of taurine in mediating the reinforcing effects of ethanol is less likely.

Most of the prevailing in vivo data have used microdialysis coupled with HPLC-based analysis in which samples are collected every 10 to $15 \mathrm{~min}$, precluding temporal resolution sufficient to determine the relationship between the release of taurine with that of dopamine, GABA, or glutamate. Capillary electrophoresis coupled with laser-induced fluorescence detection (CE-LIF) has recently been adapted to measure in vivo extracellular levels of amino acids with much higher temporal resolution (Bowser and Kennedy, 2001; Lada and Kennedy, 1996), which provides the means to examine neuronal processes (Lada et al., 1998). A potentially powerful method, microdialysis with rapid on-line CE-LIF, had not previously been used to measure the effects of ethanol in freely moving animals.

\section{METHODS}

\section{Animals}

Male Sprague Dawley® rats, 70 to 90 days of age (Harlan, Indianapolis, IN), weighing 250 to $350 \mathrm{~g}$ were housed two to three per cage in a temperature- and humidity-controlled environment with a $12 \mathrm{hr}$ normal phase light/dark cycle. All testing and training were conducted during the light phase. The subjects had ad libitum access to food and water throughout the experiment unless otherwise indicated. All procedures were con- ducted in strict adherence to the National Institute of Health Guide for the Care and Use of Laboratory Animals.

\section{Chemicals}

$\mathrm{NaCl}, \mathrm{CaCl}_{2}, \mathrm{KCl}, \mathrm{MgSO}_{4}$, o-phthaldialdehyde (OPA), $\beta$-mercaptoethanol (BME), sodium tetraborate, and hydroxypropyl- $\beta$-cyclodextrin (HPBCD) were purchased from Sigma Chemical (St. Louis, MO). Ethanol (95\%) was obtained from Aaper Alcohols and Chemicals (Shelbyville, KY). Saline was purchased from Baxter Healthcare Corporation (Deerfield, IL).

\section{Surgeries}

Each rat was anesthetized with $86 \mathrm{mg} / \mathrm{kg}$ ketamine and $13 \mathrm{mg} / \mathrm{kg}$ xylazine and placed in a stereotaxic apparatus for surgical implantation of a guide cannula. The guide cannula (21 gauge; Plastics One, Roanoke, VA) was positioned above the left side of the dorsal striatum (DS) or VS using the following coordinates: DS, +0.8 anteroposterior, +3.0 lateral to bregma, -4.0 dorsoventral to skull; VS, +1.6 anteroposterior, +1.7 lateral, -6.2 dorsoventral. The guide cannula was secured to the skull with dental cement anchored by three stainless steel screws. After surgery, each rat was housed separately and allowed to recover for 5 to 7 days with daily handling to ensure patency of the guide cannula and to minimize handling stress during subsequent measurements.

\section{Microdialysis}

Microdialysis probes (outer diameter $270 \mu \mathrm{m}$; active length $2 \mathrm{~mm}$ for the VS and $3 \mathrm{~mm}$ for DS; cellulose membrane, 13,000 molecular weight cutoff) were constructed by the method of Pettit and Justice (1991). On the day of the experiment, each rat was lightly anesthetized with halothane and moved into the dialysis cage, and the guide cannula was cleared for insertion of the dialysis probe. The probe was perfused with artificial cerebrospinal fluid (ACSF; $145 \mathrm{mM} \mathrm{NaCl}, 2.8 \mathrm{mM} \mathrm{KCl}, 1.2 \mathrm{mM} \mathrm{MgSO}_{4}$, $1.2 \mathrm{mM} \mathrm{CaCl}_{2}$ ) at $1 \mu \mathrm{l} / \mathrm{min}$. After probe insertion, each rat was placed in a clear polyurethane test box $(93 / 8$ in. $\times 18$ in. $\times 10$ in. deep $)$ with bedding, water bottle, and food. After this procedure, samples were taken every $11 \mathrm{sec}$ for 4 to $6 \mathrm{~min}$ (20-30 samples), and this was repeated every $15 \mathrm{~min}$ for the first $90 \mathrm{~min}$ after probe implantation. About $2 \mathrm{hrs}$ after probe insertion, saline $(1 \mathrm{ml} / \mathrm{kg}$ body weight, $0.9 \% \mathrm{NaCl})$ was injected intraperitoneally and 285 samples $(55 \mathrm{~min})$ were taken. Subsequent injections of ethanol $(20 \% \mathrm{w} / \mathrm{v}$ in saline, intraperitoneally) occurred in the following order at $1 \mathrm{hr}$ intervals: $0.5 \mathrm{~g} / \mathrm{kg}, 1 \mathrm{~g} / \mathrm{kg}$, and $2 \mathrm{~g} / \mathrm{kg}$. After each injection, 285 samples were collected. The amino acid concentrations in dialysate samples were analyzed on-line by CE-LIF. A calibration curve was generated either before or after the experiment by placing the tip of the dialysis probe in three different concentrations of a standard solution containing glutamate, aspartate, GABA, taurine, dopamine, serine, and glycine and collecting 30 samples each. The mean relative fluorescence of all samples was converted to concentration through the use of the calibration curve (a plot of peak height versus standard concentration).

After microdialysis, rats were killed by rapid decapitation. Brains were removed and frozen at $-20^{\circ} \mathrm{C}$, and $30 \mu \mathrm{m}$ sections were taken to verify probe placement.

\section{$C E-L I F$}

Amino acids were measured by CE-LIF using the procedure established by Bowser and Kennedy (2001). Primary amine moieties in the dialysate were derivatized on-line by mixing with a $1 \mu \mathrm{l} / \mathrm{min}$ stream of OPA solution (10 mM OPA, $40 \mathrm{mM}$ BME, $36 \mathrm{mM}$ borate, $0.81 \mathrm{mM}$ HPBCD $10 \%$ methanol $\mathrm{v} / \mathrm{v}, \mathrm{pH} 9.5$ ) with a reaction time of approximately $1.5 \mathrm{~min}$. The reaction time did not limit the temporal resolution of the measurement; however, it did induce a 3 to 5 min delay between changes occurring at the dialysis probe and their detection by the CE system. Samples of the dialysate were injected onto the capillary using a flow-gate interface as follows. The outlet of the reaction capillary was aligned with 
the inlet of the CE separation capillary $(10 \mathrm{~cm}$ long, $10 \mu \mathrm{m}$ inner diameter, $150 \mu \mathrm{m}$ outer diameter, fused-silica) in a Plexiglas block, leaving a gap of approximately $30 \mu \mathrm{m}$. A $1 \mathrm{ml} / \mathrm{min}$ cross-flow was applied between the capillaries, which carried the sample solution to waste. To inject a plug of sample, the cross-flow was stopped for $1 \mathrm{sec}$ allowing the sample to fill the gap between capillaries, and the voltage was then raised to $-2 \mathrm{kV}$ for 100 msec. After injection, the gating cross-flow was resumed to wash excess dialysate to waste, and the separation voltage was ramped from $2 \mathrm{kV}$ to 20 $\mathrm{kV}$ over $500 \mathrm{msec}$ using a CZE1000R high-voltage power supply (Spellman High Voltage, Hauppauge, NY).

The OPA-labeled amino acids were detected using LIF in a sheath-flow detector cell. The outlet of the separation capillary was inserted into a 2 $\mathrm{mm}$ square outer diameter, $200 \mu \mathrm{m}$ square inner diameter quartz cuvette (Mindrum Precision, Rancho Cucamonga, CA). Grinding the outlet of the separation capillary to a point reduced the dead volume at the detection point. Sheath buffer ( $40 \mathrm{mM}$ borate, $\mathrm{pH}=9.5$ ) was siphoned around the outside of the separation capillary. This arrangement reduces the background signal caused by laser scatter as well as background fluorescence caused by impurities in the fused silica. Fluorescence was excited using the $351 \mathrm{~nm}$ line (20 mW total UV) of an argon-ion laser (Enterprise II 622; Coherent Laser Group, Santa Clara, CA) focused onto the analytes using a $1 \mathrm{X}$ fused silica lens (Newport Corp., Irvine, CA). Emission was collected at a $90^{\circ}$ angle using a $60 \mathrm{X}, 0.7$ N.A. long-working distance objective (Universe Kogaku, Oyster Bay, NY), spatially filtered using an iris, passed through a $450 \pm 25 \mathrm{~nm}$ bandpass (Melles Groit, Irvine, CA), and collected on a photomultiplier tube (PMT, R1477; Hamamatsu, Bridgewater, NJ). Current from the PMT was amplified, filtered (10 msec rise time), and sampled using LabView 5.0 (National Instruments, Austin TX). Sample electropherograms are shown in Fig. 1 after saline (panel A) or ethanol (panel B) injections.

\section{HPLC}

For some experiments, dialysate was collected at 15 min intervals (flow rate $=2 \mu \mathrm{l} / \mathrm{min}$ ) and frozen, and then taurine content was measured at a later date using HPLC with electrochemical detection (Dawson and Wallace, 1992). Samples were derivatized before HPLC by reacting $20 \mu \mathrm{l}$ of dialysate and $180 \mu \mathrm{l}$ of mobile phase with $175 \mu \mathrm{l}$ of a $9 \mathrm{mM}$ OPA/ $/ 0.5 \%$ BME solution in a $0.1 \mathrm{M}$ disodium borate solution $(\mathrm{pH} 10.0)$ for exactly 2 min. The derivatization reaction was terminated by adding $25 \mu 10.4 \mathrm{M}$ iodoacetamide, which also served to diminish electrochemical interference by OPA. Derivatized dialysate $(250 \mu \mathrm{l})$ was injected onto a reversed-phase column (Microsorb-MV, $4.6 \mathrm{~mm}$ inner diameter $\times 10 \mathrm{~cm}, \mathrm{C}_{18}$ with $3 \mu \mathrm{m}$ packing material; Rainin, Woburn, MA), and mobile phase was pumped at $0.7 \mathrm{ml} / \mathrm{min}$ (PM-11, Bioanalytical Systems, West Lafayette, IN). Derivatized taurine was detected using an $\mathrm{Ag} / \mathrm{AgCl}$ reference electrode and a glassy carbon working electrode at an applied voltage of $0.725 \mathrm{~V}$ (LC-4B, Bioanalytical Systems, West Lafayette, IN). Sample taurine concentrations were calculated by a Hewlett Packard integrator (model 3390A, Avondale, PA) based on external standards prepared and injected daily.

\section{Dialysate Ethanol Determinations}

Dialysate ethanol content was measured using headspace gas chromatography with an automated solid phase microextraction (SPME) procedure. A Varian 2800 gas chromatograph was equipped with a Supelcowax-10 megabore column $(15 \mathrm{~mm} \times 0.53 \mathrm{~mm} ; 0.5 \mu \mathrm{m}$ film). The injector was set to $175^{\circ} \mathrm{C}$, the column oven was $65^{\circ} \mathrm{C}$, and the flame ionization detector was $220^{\circ} \mathrm{C}$. Samples were heated to $65^{\circ} \mathrm{C}$ for $15 \mathrm{~min}$ before analysis. The SPME of the headspace was carried out in an 8200 autosampler using 3 min absorption and 2 min desorption. The SPME fiber was coated with carboxenpolydimethylsiloxane $(75 \mu \mathrm{m})$. Ethanol concentrations were quantified by comparison to external standards. The lowest standard run routinely was $0.3125 \mathrm{mM}$, which gave a signal to noise ratio of 10
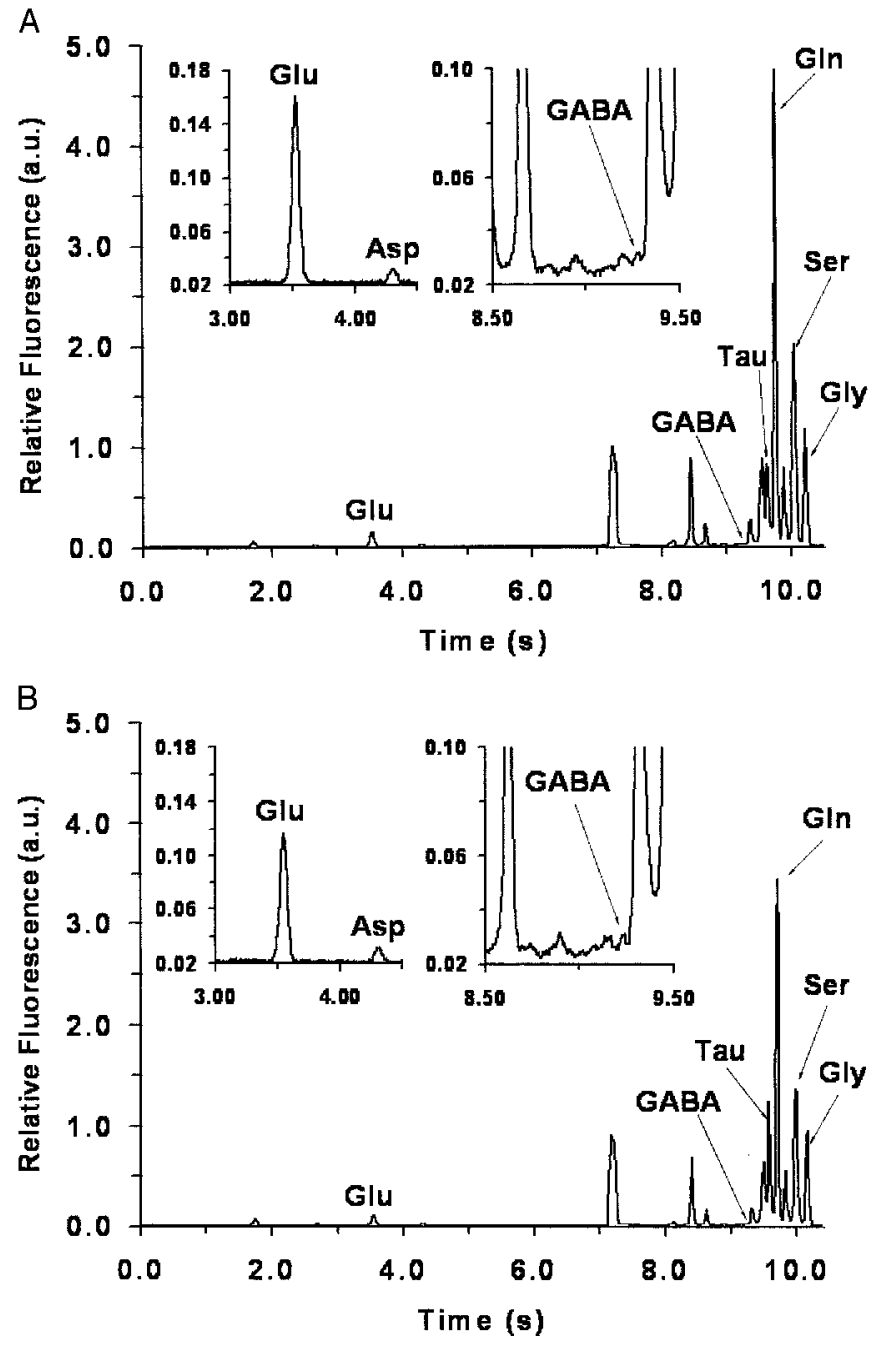

Fig. 1. Representative electropherograms of dialysate from VS collected under basal microdialysis conditions or from the same animal after it received $2.0 \mathrm{~g} / \mathrm{kg}$ ethanol as described for Fig. 3. Insets are close-ups of the electropherogram to facilitate viewing of the glutamate, aspartate, and GABA peaks. Note the selective increase in only the taurine peak caused by ethanol.

\section{Data Analysis}

The first 20 samples collected in each CE-LIF experiment (preinjection) were used to calculate a baseline of $100 \%$. Subsequent data were expressed as a percent of this baseline and are depicted in each figure as the mean \pm SEM. For statistical purposes, the mean of each five samples was calculated and subjected to a three-way ANOVA with unweightedmeans solution for unequal $n$ using brain region, dose, and time period as variables for each analyte. To follow up significant time interactions, data were divided into first $20 \mathrm{~min}$, second $20 \mathrm{~min}$, and last $12 \mathrm{~min}$ after injection and analyzed separately. A significance level of $p<0.05$ was used for all statistical analyses. Only those subjects with accurate probe placements (Fig. 2) were included in the analysis.

\section{RESULTS}

Acute injection of ethanol increased taurine levels in the DS and VS in a dose-dependent manner; however, the VS displayed a higher sensitivity to ethanol, responding with greater magnitude and to lower doses than did DS (Fig. 3). In the VS (Fig. 3A), the largest increase in taurine levels 

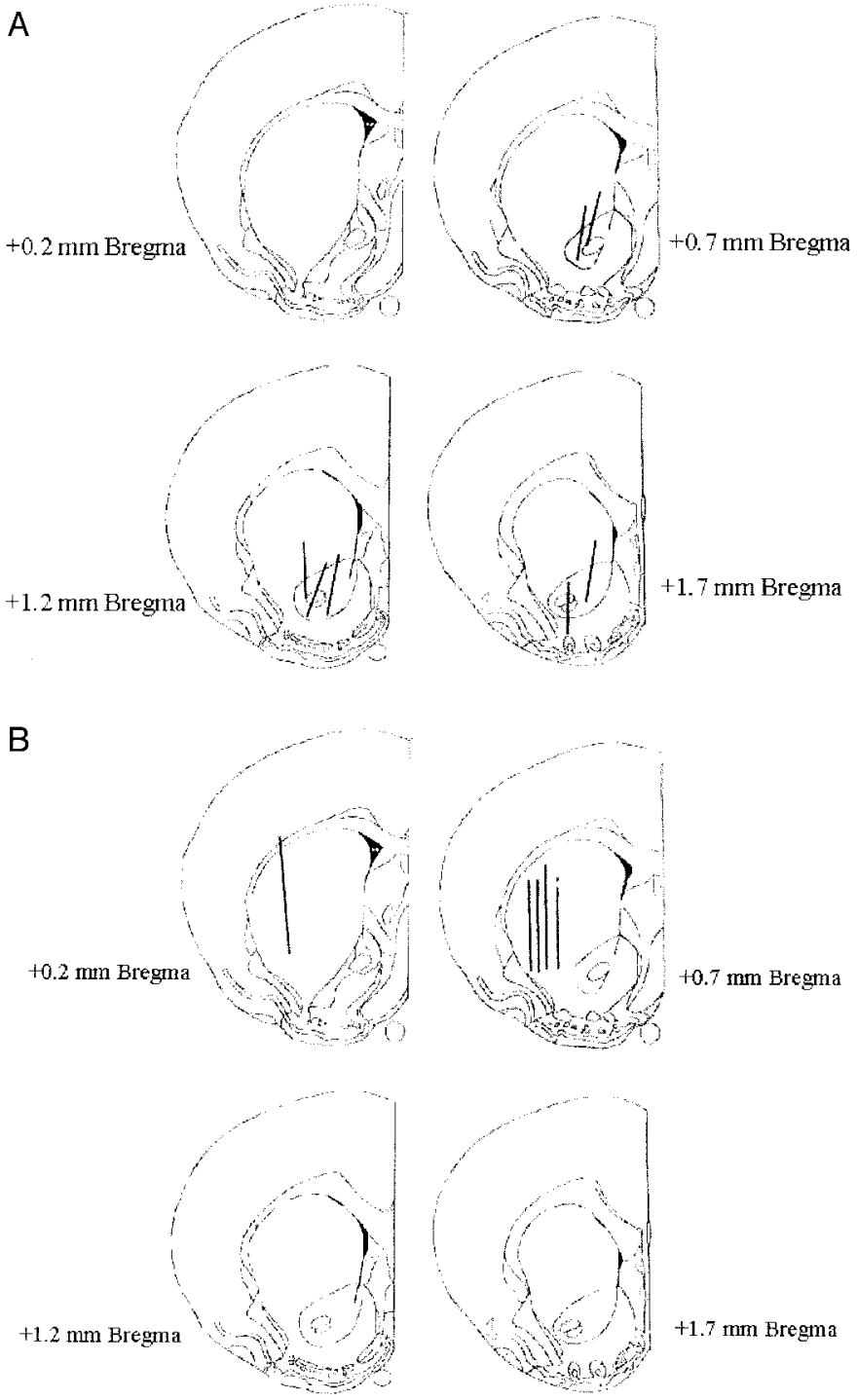

+1.7 mm Bregma

Fig. 2. Probe placements shown in coronal sections from VS (A) or DS (B). The coronal sections shown are from Paxinos and Watson (1997).

(90 $\pm 15 \%$ above baseline) occurred 5 to $15 \mathrm{~min}$ after the $2 \mathrm{~g} / \mathrm{kg}$ injection, after which taurine levels gradually stabilized to $30 \pm 7 \%$ above basal until the end of the sampling period. The $1 \mathrm{~g} / \mathrm{kg}$ dose increased taurine levels for about 15 min with a maximal increase of $28 \pm 8 \%$. A slightly lower magnitude of increase $(20 \pm 9 \%)$ was observed after the $0.5 \mathrm{~g} / \mathrm{kg}$ dose with a somewhat shorter duration. There was a slight elevation in taurine levels for 5 min after saline injection, never reaching a $10 \%$ increase from basal values.

The DS was less sensitive to the ethanol injection (Fig. 3B). The highest dose of ethanol maximally increased taurine levels by only $25 \pm 9 \%$ above baseline for $30 \mathrm{~min}$. Similarly, 0.5 and $1 \mathrm{~g} / \mathrm{kg}$ ethanol intraperitoneally increased taurine by a maximum of only $15 \pm 5 \%$ above baseline levels. The saline injection also increased taurine levels by $15 \pm 5 \%$ but only for about $5 \mathrm{~min}$, after which taurine levels returned to a stable baseline for the duration of sampling.
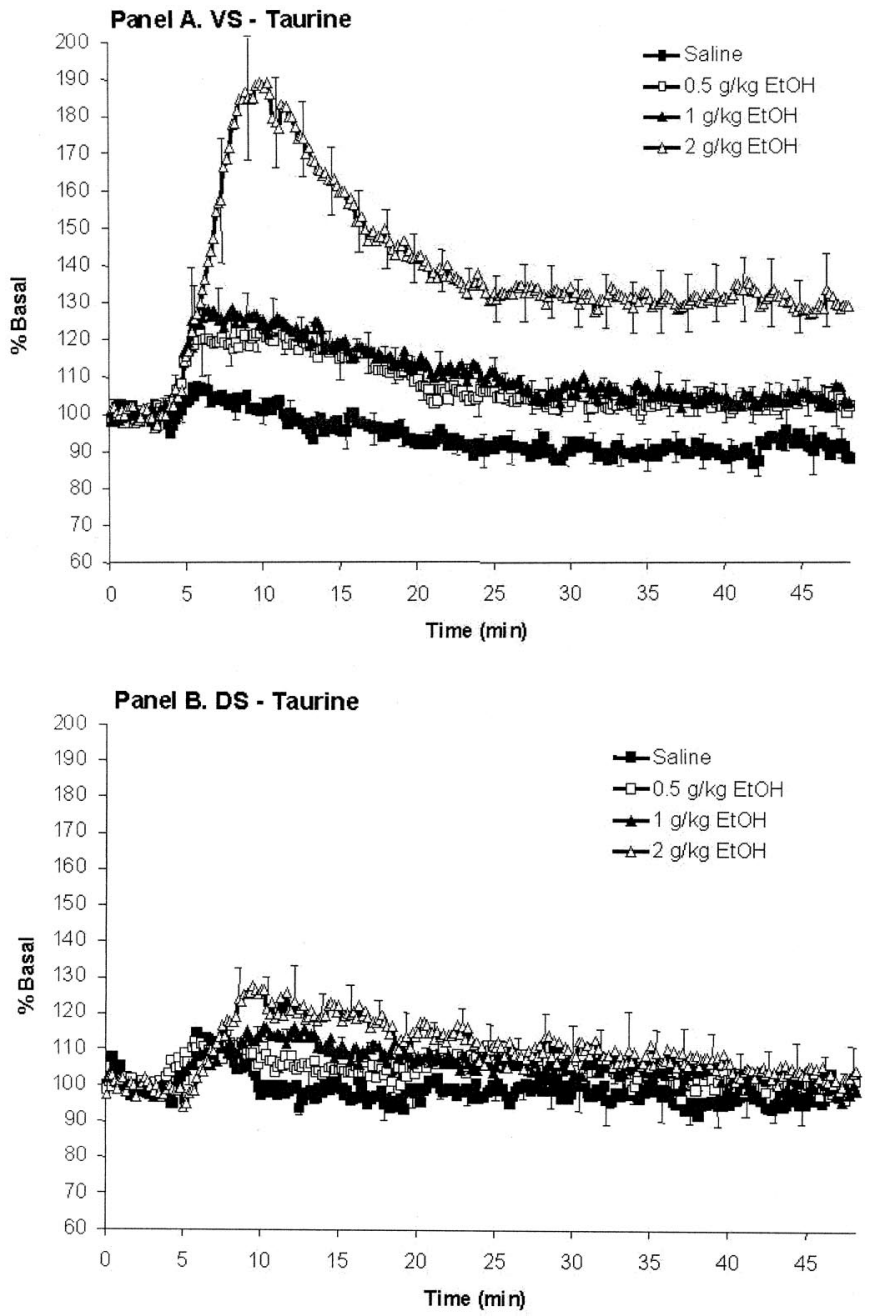

Fig. 3. Ethanol-induced changes in taurine. The change in taurine levels in microdialysate from (A) the VS $(n=7)$ and $(B)$ the DS $(n=5)$ of rats after saline or $0.5,1.0$, or $2.0 \mathrm{~g} / \mathrm{kg}$ intraperitoneal ethanol injections given in a series of injections. Microdialysate was sampled for $1 \mathrm{hr}$ after each injection. The injection occurred at the start of each $1 \mathrm{hr}$ sampling period, but there was approximately a 5 min delay for dialysate to travel from the probe tip to the flow-gate. Data were calculated as a percent of the mean \pm SEM relative fluorescence of the first 20 samples (basal efflux, see Fig. 7).

These observations were supported by the results of a three-way ANOVA as follows. An overall significant brain region $\times$ dose $\times$ time interaction $[F(156,1560)=1.85, p<$ $0.001]$ was detected. During the first 20 min of sampling, there was a significant brain region $\times$ dose $\times$ time interaction $[F(57,570)=3.65, p<0.001]$, which was primarily due to a significant region $\times$ time interaction at the $2 \mathrm{~g} / \mathrm{kg}$ dose $[F(19,190)=6.17 ; p<0.001]$ but not after any of the other injections. There were significant dose $\times$ time interactions for both the VS $[F(57,342)=11.6, p<0.001]$ and DS $[F(57,228)=3.43, p<0.001]$ and significant main effects of time after all injections in both brain regions [VS, $F(19,114)$ ranged from 2.22 to 21.6 ; DS, $F(19,76)$ ranged from 2.91 to 6.11; $p$ at least $<0.05$ ]. During the 20 to $40 \mathrm{~min}$ after injection, ANOVA revealed only significant two-way interactions of region $\times$ dose $[F(3,30)=4.52, p<0.01]$ and 
region $\times$ time $[F(19,190)=5.63, p<0.001]$, which was primarily due to a significant main effect of dose only in the VS $[F(3,18)=17.5, p<0.001]$. Follow-up analyses indicated a significant main effect of region after the $2 \mathrm{~g} / \mathrm{kg}$ dose $[F(1,10)=6.11 ; p<0.05]$ but not after saline or 0.5 or $1 \mathrm{~g} / \mathrm{kg}$ ethanol. During the last $12 \mathrm{~min}$ after injection, the interaction between brain region and dose was no longer significant $[F(3,30)=2.74, p=0.06]$.

When the effect of the same series of ethanol injections on glutamate levels was measured and compared with taurine, a very different time course of changes was seen. That is, no effect occurred at any dose until at least 10 to $15 \mathrm{~min}$ after injection in both brain regions (Fig. 4). At this point, $2 \mathrm{~g} / \mathrm{kg}$ ethanol began to decrease glutamate levels in both the DS and the VS by $10 \%$ to $15 \%$, whereas $0.5 \mathrm{~g} / \mathrm{kg}$ ethanol increased glutamate levels, particularly in the DS. Specifically, $0.5 \mathrm{~g} / \mathrm{kg}$ increased glutamate levels in the DS (Fig. 4B) starting at 20 min to reach a maximum increase of $60 \pm 30 \%$ above baseline by the end of the sampling period. However, this large magnitude increase occurred in
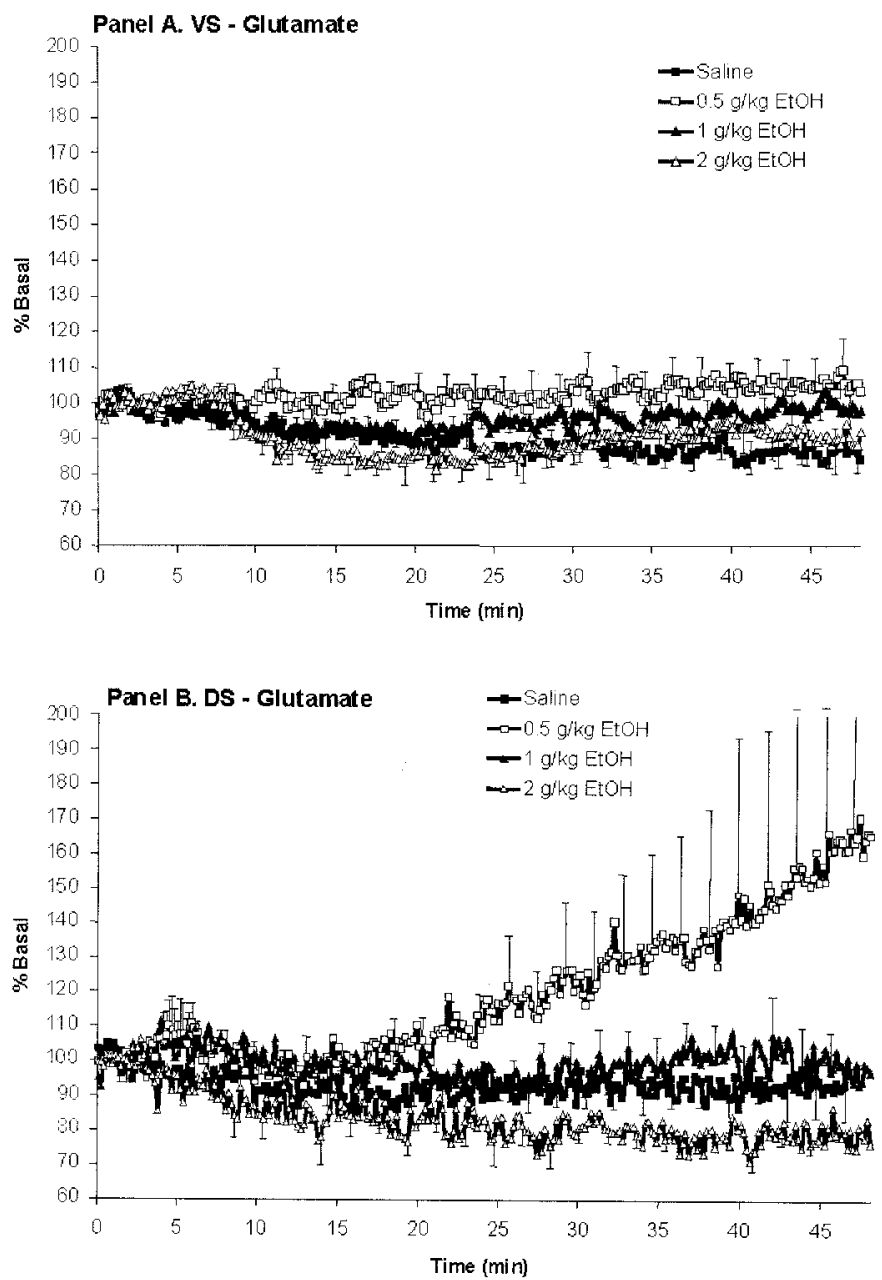

Fig. 4. Ethanol-induced changes in glutamate. Glutamate levels in microdialysate from (A) the VS $(n=7)$ and (B) the DS $(n=5)$ of rats after saline or $0.5,1.0$, or $2.0 \mathrm{~g} / \mathrm{kg}$ intraperitoneal ethanol injections given in a series of injections. Microdialysate was sampled and data calculated as described for Fig. 3. only two of five subjects, explaining the large SEMs. The $0.5 \mathrm{~g} / \mathrm{kg}$ dose of ethanol also caused a small increase in glutamate in the VS, which was primarily due to larger magnitude increases in three of seven rats tested. There was no change in glutamate levels after the saline or $1 \mathrm{~g} / \mathrm{kg}$ injection for either region.

These observations were supported by an overall significant brain region $\times$ dose $\times$ time interaction $[F(156,1560)$ $=1.54, p<0.001]$. The glutamate data from the first 20 , second 20, and last 12 min of sampling were subjected to a three-way ANOVA. During the first 20 min after injection, there was an overall dose $\times$ time interaction $[F(57,570)=$ $2.15, p<0.001$ ], which was due to a main effect of time after the $2 \mathrm{~g} / \mathrm{kg}$ injection $[F(19,190)=10.8, p<0.001]$. There was no significant effect of brain region. On the other hand, there were significant region $\times$ dose $\times$ time interactions during the second $20 \mathrm{~min}[F(57,570)=1.95, p$ $<0.001]$ and last $12 \min [F(33,330)=1.61, p<0.05]$, which were due to an effect of dose in the DS $[F(3,12)=4.20, p$ $<0.05$ ] but not the VS and an effect of time after only the 0.5 and $2 \mathrm{~g} / \mathrm{kg}$ injections $[F(19,190)=1.95$ and 2.02 , respectively, $p<0.01]$.

Acute ethanol slowly decreased glycine levels in a doserelated manner in both the VS and the DS (Fig. 5). The 2 $\mathrm{g} / \mathrm{kg}$ dose maximally decreased glycine by $25-30 \%$ after 45 min whereas $1 \mathrm{~g} / \mathrm{kg}$ decreased glycine by $10 \%$ to $15 \%$ over time, and neither saline nor $0.5 \mathrm{~g} / \mathrm{kg}$ affected glycine levels. Overall, there was no significant effect of brain region $\times$ dose $\times$ time $[F(156,1560)=0.67, p<0.99]$. However, there was a significant dose $\times$ time interaction $[F(57,570)$ $=2.74, p<0.001]$ during the first 20 min after injection and significant dose main effects during the second $20 \mathrm{~min}$ $[F(3,30)=6.40, p<0.01]$ and the last $12 \min [F(3,30)=$ $5.43, p<0.01]$. There was a region $\times$ time interaction during the first $20 \min [F(57,570)=3.65, p<0.001]$, which was due to a greater overall effect of time in the VS than the DS.

Ethanol slowly decreased serine levels by about $10 \%$ to $20 \%$ in the VS and DS (Fig. 6), especially at the higher doses tested. These observations were supported by a significant overall brain region $\times$ dose $\times$ time interaction $[F(156,1560)=1.28, p<0.05]$. There was a significant dose $\times$ time interaction $[F(57,570)=3.19, p<0.001]$ during the first $20 \mathrm{~min}$ after injection and significant dose effects during the second $20 \min [F(3,30)=4.20, p<0.05]$ and the last $12 \min [F(3,30)=6.12, p<0.01]$. There were no main effects or interactions involving brain region. There were no systematic effects of ethanol on GABA levels in the VS and a small inhibitory effect (about 15\%) of the highest ethanol dose in the DS (data not shown). However, ANOVA of these data did not indicate any significant main effects or interactions during any of the time periods after injection.

To determine whether there were residual effects of the repeated injections of saline and $0.5 \mathrm{~g} / \mathrm{kg}, 1 \mathrm{~g} / \mathrm{kg}$, and $2 \mathrm{~g} / \mathrm{kg}$ ethanol, basal levels of amino acids in dialysate were com- 

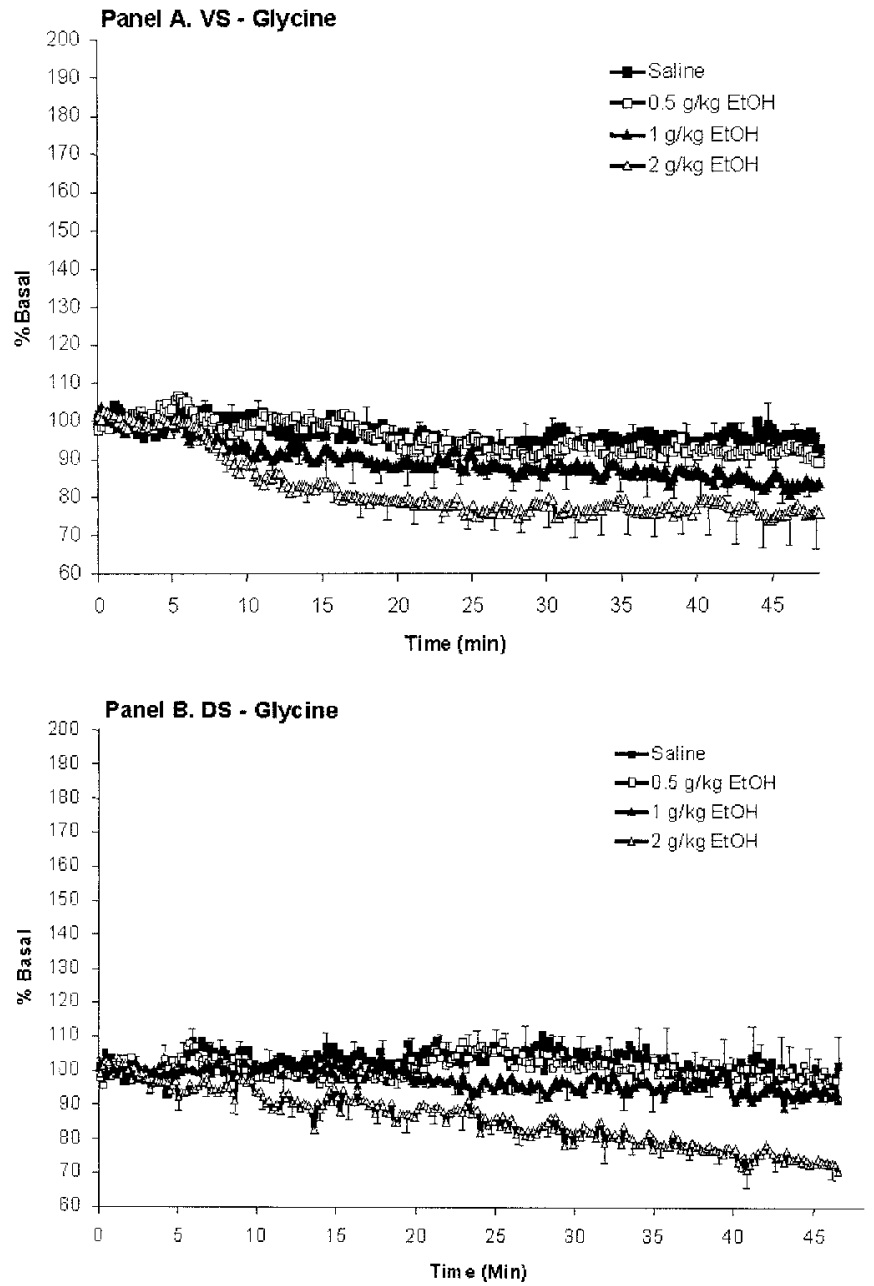

Fig. 5. Ethanol-induced decreases in glycine. The change in glycine levels in microdialysate from (A) the VS $(n=7)$ and $(B)$ the DS $(n=5)$ of rats after saline or $0.5,1.0$, or $2.0 \mathrm{~g} / \mathrm{kg}$ intraperitoneal ethanol injections given in a series of injections. Microdialysate was sampled and data calculated as in Fig. 3.

pared. Figure 7 is the mean amino acid concentration calculated from the first $2011-\mathrm{sec}$ samples (i.e., the first 3.5 min of sampling) for taurine, glycine, glutamate, and GABA in microdialysate from the VS (Fig. 7A) and DS (Fig. 7B) after each injection. Basal values for the treatments in the VS did not significantly deviate from one treatment to the next $[F(3,18)<1.0$, nonsignificant for all analytes]. Likewise, the DS basal values for the amino acids measured did not significantly change from treatment to treatment $[F(3,12)$ ranged from 0.44 to 1.23 , nonsignificant for all analytes]. It was also apparent from these data that all amino acids had reached stable levels by $2 \mathrm{hrs}$ after probe insertion.

To compare the sensitivity of the CE-LIF assay to conventional microdialysis methods, we injected rats with saline or $1 \mathrm{~g} / \mathrm{kg}$ ethanol (in a counterbalanced fashion) and collected dialysate samples from DS every 15 min that were subsequently analyzed for taurine using HPLC. Taurine levels in the striatum were significantly elevated by both saline and ethanol injections (Fig. 8). The $1 \mathrm{~g} / \mathrm{kg}$ dose of
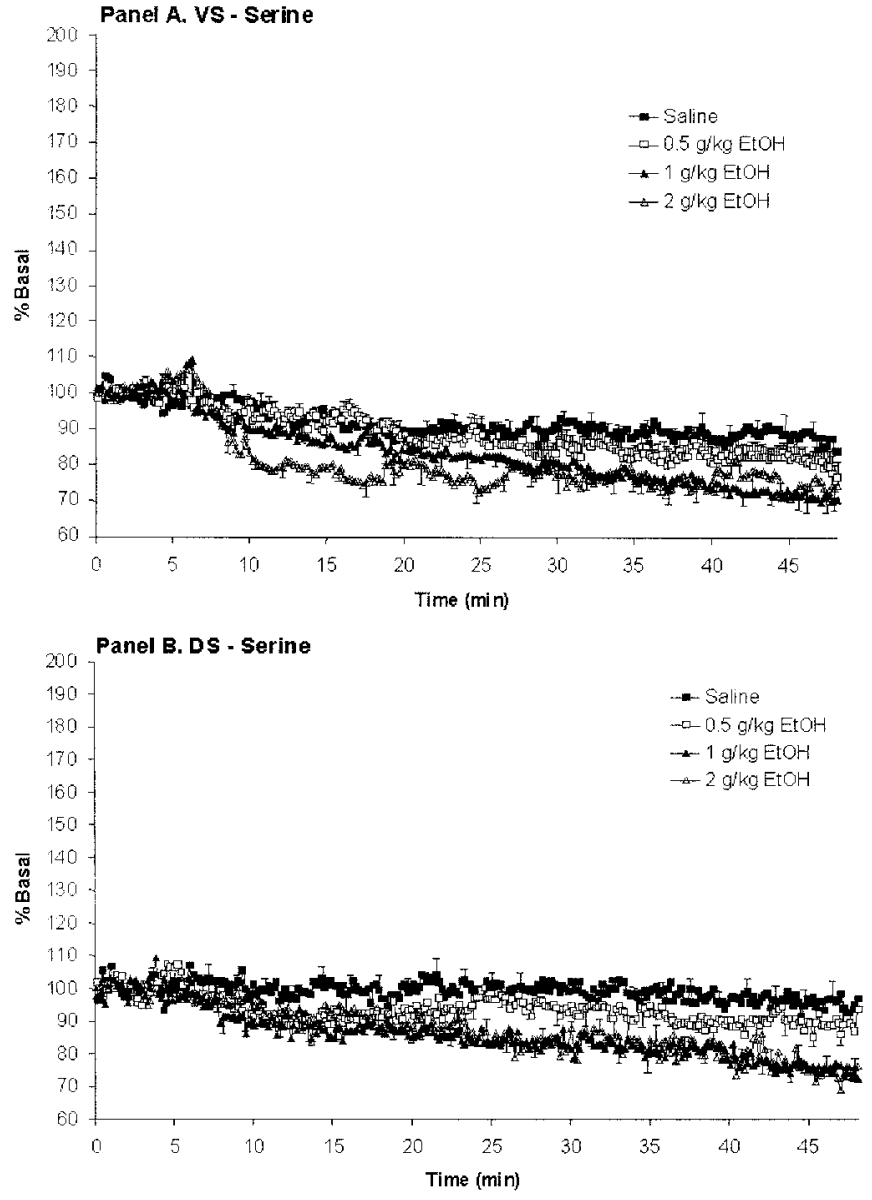

Fig. 6. Ethanol-induced decreases in serine. Serine levels in microdialysate from (A) the VS $(n=7)$ and (B) the DS $(n=5)$ of rats after saline or $0.5,1.0$, or 2.0 $\mathrm{g} / \mathrm{kg}$ intraperitoneal ethanol injections given in a series of injections. Microdialysate was sampled and data were calculated as described in Fig. 3.

ethanol increased taurine above basal levels at the $15 \mathrm{~min}$ interval, as confirmed by a significant main effect of time $[F(17,85)=3.39, p<0.001]$. The saline injection also increased taurine above basal levels at the $15 \mathrm{~min}$ interval $[F(5,25)=2.82, p<0.05]$. However, there was no significant main effect or interaction involving the type of injection (saline versus ethanol).

To compare the dialysate ethanol concentrations between the two types of ethanol exposure (four cumulative escalating doses versus one $1 \mathrm{~g} / \mathrm{kg}$ dose), we compared dialysate ethanol levels in the animals used in Fig. 8 with those of an additional three animals experiencing the series of cumulative injections as used in Figs. 3 through 7 but with dialysate collected every $10 \mathrm{~min}$. The $1 \mathrm{~g} / \mathrm{kg}$ ethanol injection, when given alone, increased brain dialysate ethanol levels to about $10 \mathrm{mM}$ within the first 15 min after injection, which then took approximately $3 \mathrm{hr}$ to return to basal levels (Fig. 9 and data not shown). The first injection of $0.5 \mathrm{~g} / \mathrm{kg}$ ethanol increased brain ethanol levels to about $7 \mathrm{mM}$, which then decreased to about $4 \mathrm{mM}$ just before the second injection of $1.0 \mathrm{~g} / \mathrm{kg}$. This injection raised brain dialysate ethanol to about $14 \mathrm{mM}$, where it remained fairly 

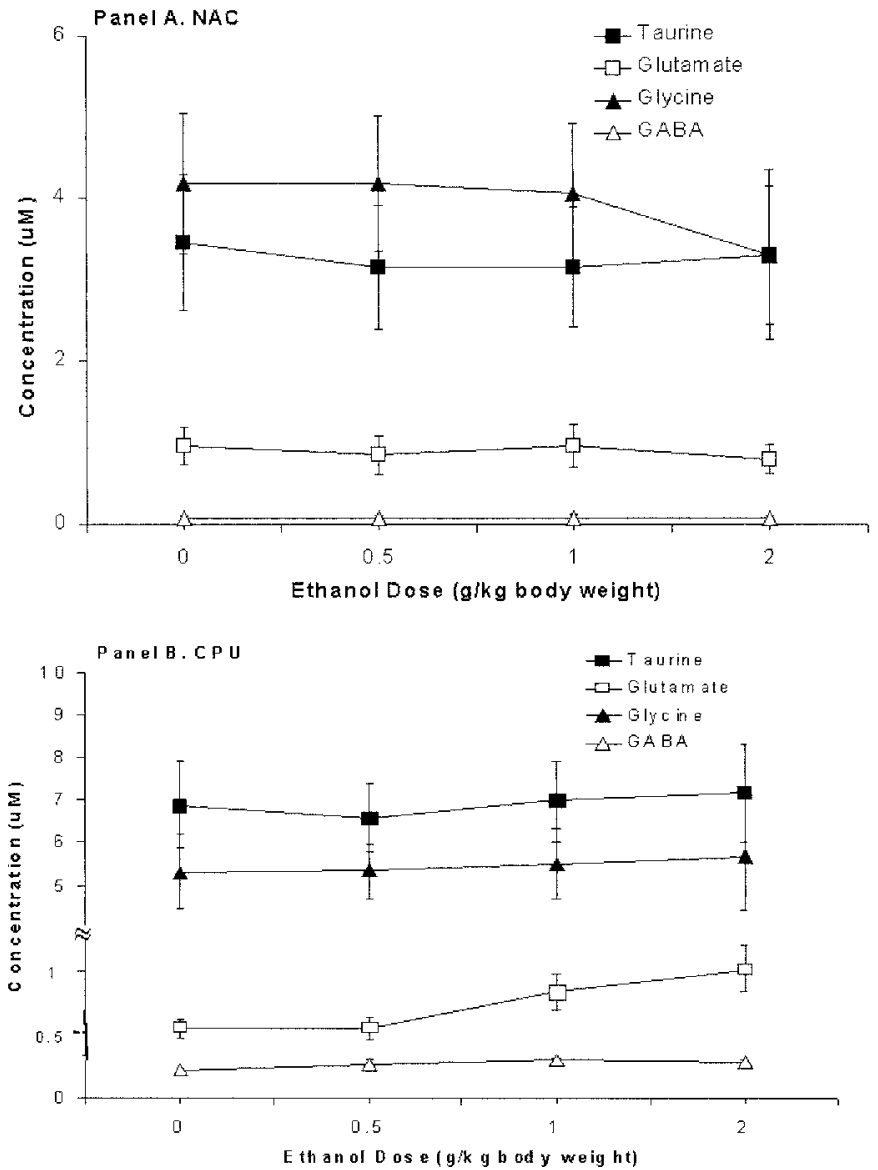

Fig. 7. Basal dialysate levels of amino acids. The mean concentrations for taurine, glycine, glutamate, and GABA in microdialysate under basal conditions from (A) the VS $(n=7)$ and (B) the DS $(n=5)$ of rats before saline or $0.5,1.0$, or $2.0 \mathrm{~g} / \mathrm{kg}$ intraperitoneal ethanol injections given in a series of injections. The mean basal values were calculated from the first 20 samples at the beginning of each 1 $\mathrm{hr}$ sampling period. There was no effect of prior injections on the basal levels of any analytes measured.

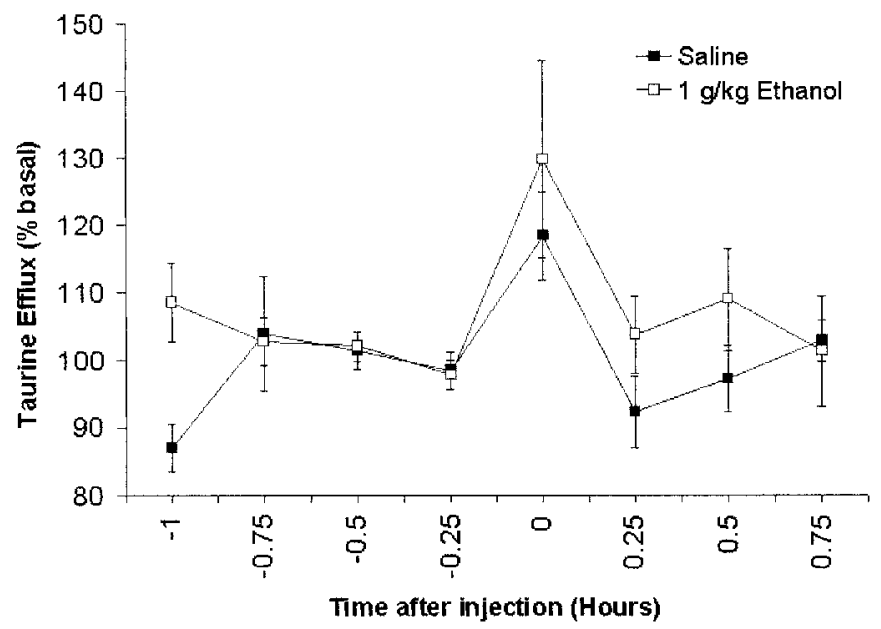

Fig. 8. HPLC determination of ethanol-induced taurine efflux. The level of taurine in microdialysis samples from DS of rats for $1 \mathrm{hr}$ before and after a saline or $1 \mathrm{~g} / \mathrm{kg}$ intraperitoneal ethanol injection. Samples were collected every $15 \mathrm{~min}$ and subjected to HPLC analysis. Data are expressed as a percent of the mean taurine level in the two samples before injection $(1.10 \pm 0.25 \mu \mathrm{M}$ for saline; 1.14 $\pm 0.26 \mu \mathrm{M}$ for ethanol). Shown are mean \pm SEM for $n=7$.

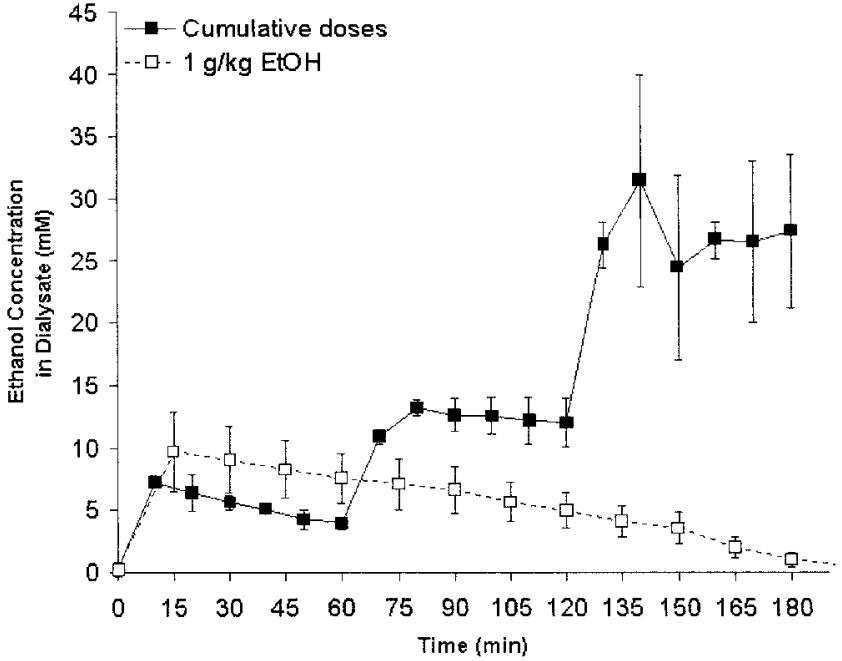

Fig. 9. Brain dialysate ethanol levels. The level of ethanol in microdialysis samples from DS after one injection of ethanol $(1 \mathrm{~g} / \mathrm{kg})$ or after a series of ethanol injections as follows: $0.5 \mathrm{~g} / \mathrm{kg}$ at $1 \mathrm{~min}, 1.0 \mathrm{~g} / \mathrm{kg}$ at $61 \mathrm{~min}$, and $2.0 \mathrm{~g} / \mathrm{kg}$ at 121 min. Shown are mean \pm SEM for $n=3-5$.

constant until the final ethanol injection of $2 \mathrm{~g} / \mathrm{kg}$. This injection further raised brain ethanol levels to about 30 $\mathrm{mM}$, where they remained stable for the duration of the experiment.

To ascertain whether the ability of ethanol to affect amino acid levels was a direct effect of ethanol on the cells surrounding the microdialysis probe, ethanol was perfused directly into the VS. In this CE-LIF experiment, a series of concentrations $(50 \mathrm{mM}, 500 \mathrm{mM}, 1 \mathrm{M})$ of ethanol was perfused $(1 \mu \mathrm{L} / \mathrm{min})$ by reverse dialysis into the VS and samples were collected every $11 \mathrm{sec}$ for $30 \mathrm{~min}$ at each concentration (Fig. 10). Increasing the concentration of ethanol in the ACSF had no effect on taurine levels but caused a concentration-dependent increase in both glutamate and glycine levels by about $30 \%$ to $40 \%$ above base-

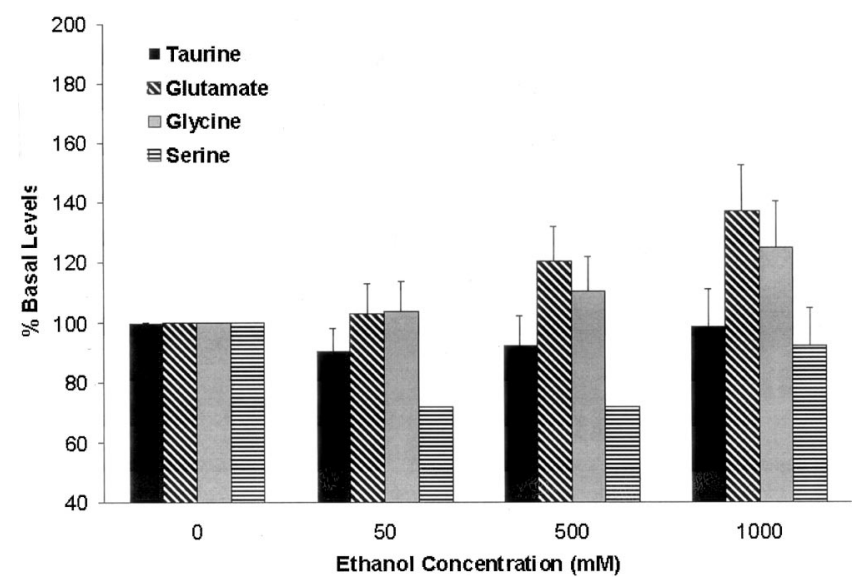

Fig. 10. Taurine, glutamate, glycine, and serine levels after direct exposure to different concentrations of ethanol via reverse dialysis. Data are expressed as a percent of the mean analyte concentration in the 15 samples ( $3 \mathrm{~min}$ ) before changing ACSF ethanol content (taurine $=3.9 \pm 1.6 \mu \mathrm{M}$, glutamate $=0.2 \pm 0.1$ $\mu \mathrm{M}$, glycine $=2.7 \pm 1.0 \mu \mathrm{M}$, serine $=2.1 \pm 0.8 \mu \mathrm{M})$. Shown are mean + SEM for $n=4$. 
line. On the other hand, 50 and $500 \mathrm{mM}$ ethanol tended to decrease serine levels. However, none of the effects caused by including ethanol in the ACSF resulted in amino acid levels that were significantly different from levels under control conditions.

\section{DISCUSSION}

These results provide novel support for the hypothesis that ethanol exposure causes a selective interaction with taurine levels in different regions of the brain. For the first time, increases in taurine were observed at doses that animals will self-administer and at a greater magnitude in brain regions known to be activated during positive reinforcement (VS) compared with nearby motor regions (DS). Furthermore, an early rapid increase followed by a later more persistent elevation in taurine levels was observed, suggesting a complex release mechanism. Taurine changes involved a systemic effect of ethanol rather than a local effect, which argues against this efflux being attributed solely to osmotic changes caused by local ethanol exposure. These novel observations were made possible by the first high temporal resolution monitoring of multiple amino acids in the brains of freely moving animals using microdialysis coupled to rapid on-line CE-LIF analysis.

Systemic administration of ethanol produced doserelated biphasic increases in taurine. In the VS, a $2 \mathrm{~g} / \mathrm{kg}$ dose of ethanol increased taurine levels almost 2-fold during the first $20 \mathrm{~min}$ after injection where it remained elevated by $30 \%$ for at least $1 \mathrm{hr}$. The dose-related increase in taurine seen after injections of the two higher doses of ethanol confirms previous reports in VS (Dahchour et al., 1994, 1996). However, the significant dose-related increase in taurine seen in DS and the increases in both DS and VS after $0.5 \mathrm{~g} / \mathrm{kg}$ ethanol have not previously been reported. Similarly, previous reports did not indicate a biphasic nature of the response of taurine to higher doses of ethanol. The primary difference between this work and previous studies is the decrease in sampling interval to $11 \mathrm{sec}$ from $15 \mathrm{~min}$. The conclusion that the 82-fold improvement in temporal resolution enabled these novel observations is supported by comparison of data from experiments in which HPLC analysis failed to detect an effect of $1 \mathrm{~g} / \mathrm{kg}$ ethanol in DS that was significantly different from the saline response. Additionally, the increased statistical power afforded by the larger number of samples gathered by CE-LIF, compared with only four samples per hour collected every 15 min with HPLC techniques, may have contributed to significant effects observed on exposure to both 0.5 and $1 \mathrm{~g} / \mathrm{kg}$ ethanol in DS. Thus, the use of CE-LIF in freely moving animals allowed for the detection of taurine levels evoked by clinically and behaviorally relevant doses of ethanol. The effects of the higher dose of ethanol to increase taurine by 2-fold was also found when an acute dose of $2.5 \mathrm{~g} / \mathrm{kg}$ of ethanol was given alone as well as when $2.0 \mathrm{~g} / \mathrm{kg}$ was given $2 \mathrm{hrs}$ after a $0.5 \mathrm{~g} / \mathrm{kg}$ injection and $1 \mathrm{hr}$ after a $1 \mathrm{~g} / \mathrm{kg}$ injection (Smith et al., 2003b). Additionally, our preliminary data indicate that self-administered doses as low as $0.4 \mathrm{~g} / \mathrm{kg}$ ethanol increase taurine levels in VS by about $20 \%$ as measured by on-line CE-LIF (Smith et al., 2003a).

The role of taurine in the brain and the regulation of its efflux have not yet been fully characterized. Taurine is one of the most abundant amino acids in the brain (see Huxtable, 1992; Pow et al., 2002), present in neurons as well as glia (Huxtable, 1989, 1992). Many biological roles have been proposed for taurine including neurotransmission, osmoregulation, calcium modulation, membrane stabilization, and antioxidation (Huxtable, 1992; Wright et al., 1986), all of which might contribute to alterations in extracellular taurine levels. Although only a small percentage of taurine is found in synaptic vesicles, it has been proposed as an inhibitory neurotransmitter (Davison and Kaczmarek, 1971; Huxtable, 1992; Okamoto et al., 1983). In support of this, depolarization of neuronal populations causes taurine release (Collins and Topiwala, 1974; Kaczmarek and Davison, 1972; Schousboe et al., 1990; Shain and Martin, 1990); however, this release is $\mathrm{Ca}^{2+}$-independent, $\mathrm{Cl}^{-}$-dependent, and lower in magnitude compared with other neurotransmitters (Sánchez-Olea and Pasantes-Morales, 1990; Schousboe et al., 1990). Taurine efflux can also occur via a swelling-activated channel activated by hypo-osmotic conditions (Bres et al., 2000; Boese et al., 1996). Additionally, extracellular taurine levels are regulated by the activity of a high-affinity taurine transporter (Smith et al., 1992). All of these mechanisms might contribute to altered levels of extracellular taurine caused by ethanol.

At least a portion of ethanol-induced taurine efflux has been shown to be due to osmoregulation (Lallemande et al., 2000; Quertemont et al., 2001, 2003). However, our data indicating the regional selectivity of ethanol's effects argue against this mechanism. Also contrary to the osmoregulatory hypothesis is our data that local exposure of the VS to 50 to $1000 \mathrm{mM}$ ethanol increased taurine by only $10 \%$ above baseline, which is much less than the 2-fold increase seen after the $2 \mathrm{~g} / \mathrm{kg}$ dose (resulting in $30 \mathrm{mM}$ dialysate ethanol). Unfortunately, the exact concentrations of ethanol in the brain from the reverse dialysis experiments are not known but would be assumed to be greater than $30 \mathrm{mM}$, especially at the $1000 \mathrm{mM}$ dose. The definitive evidence for determining whether the mechanism for ethanol-induced taurine efflux is neuronal or osmotic requires testing whether this efflux is dependent on signalingactivated calcium and sodium channels or whether it is more dependent on osmotically activated chloride currents. These experiments are ongoing.

Current techniques for measurement of the release of these amino acids in vivo have been called into question (Timmerman and Westerink, 1997) as only detecting extrasynaptic glutamate and GABA from nonneuronal origin. The use of the high temporal resolution CE-LIF method for measuring extracellular levels of amino acids enables 
detection of transient increases in these substances shown to be derived almost exclusively from neurogenic release (Lada et al., 1998). Although our methodology and data can only imply a neuronal origin, it is likely that ethanolinduced taurine increases, regardless of the source, have a neuronal impact. Postsynaptically, taurine stimulates chloride conductance to hyperpolarize membranes (Okamoto et al., 1983; Ye et al., 1997), presumably as an agonist at glycine and $\mathrm{GABA}_{\mathrm{A}}$ receptors (Boehm et al., 1997; Bureau and Olsen, 1991; Chattipakorn and McMahon, 2002; Haas and Hösli, 1973; Han et al., 2001; Horikoshi et al., 1988; Medina and De Robertis, 1984; Mori et al., 2002; Quinn and Harris, 1995; Schmieden et al., 1992). Because there is evidence for expression of both $\mathrm{GABA}_{\mathrm{A}}$ and glycine receptors in the VS (Martin and Siggins, 2002), taurine might alter neuronal activity via these receptors after ethanol exposure.

Given taurine's proposed role as an inhibitory neurotransmitter and our ability to view (in almost real time) a multitude of amino acids in response to ethanol, the question arises of a possible interaction of these neurotransmitter systems. Along these lines, the higher ethanol doses significantly decreased glutamate, glycine, and serine levels, a finding that has not before been reported (Dahchour et al., 1994, 1996; Quertemont et al., 2000). The time course of these changes indicates that the inhibitory effect of ethanol occurred after taurine levels were increased by ethanol. These same decreases in glutamate, serine, and cysteine were also observed when animals received only one injection of $2.5 \mathrm{~g} / \mathrm{kg}$ of ethanol (Smith et al., 2003b) compared with the cumulative injection scheme used presently. It will be interesting to test whether the decreases in these amino acids are dependent on ethanol-induced increases in taurine inhibition.

The effect of the lowest dose of ethanol on glutamate was much more complicated. In both regions, but particularly in DS, the $0.5 \mathrm{~g} / \mathrm{kg}$ dose caused a marked elevation in glutamate levels in only about half of the individual rats tested for each region. There is only one previous report that low-dose ethanol administration might increase glutamate in the VS (Moghaddam and Bolinao, 1994) compared with reports indicating no effect of 1,2 , or $3 \mathrm{~g} / \mathrm{kg}$ ethanol on glutamate (e.g., Dahchour et al., 1994, 1996). Instead, increases in glutamate are generally associated with withdrawal from ethanol (Dahchour et al., 1998; Dahchour and De Witte, 1999, 2000b, 2003; Quertemont et al., 2002).

Ethanol craving is regulated by its ability to increase neuronal firing in the mesolimbic dopamine pathway (Hodge et al., 1997; Koob et al., 1998). This effect of ethanol does not occur in all dopaminergic pathways, because ethanol decreases dopamine transmission in DS (Budygin et al., 2001). Such regional specificity may indicate a relationship between the magnitude of ethanolinduced taurine efflux and the ability of ethanol to increase dopamine transmission. Future experiments using CE-LIF can simultaneously track dopamine and taurine changes on a high-resolution time scale.

In summary, our novel observations have opened up several new lines of possible investigation including the temporal relationship between changes in taurine, dopamine, and glutamate as well as the mechanisms of taurine release caused by ethanol. The ability of CE-LIF to measure the temporal relationship between changes in these neurotransmitters, coupled with its ability to measure subtle changes in neurotransmitter levels in awake animals self-administering ethanol, should provide a tremendous opportunity to better understand the alterations in signaling that underlie the development of alcoholism.

\section{REFERENCES}

Allan AM, Harris RA (1987) Acute and chronic ethanol treatments alter GABA receptor-operated chloride channels. Pharmacol Biochem Behav 27:665-670.

Aragon CM, Amit Z (1993) Taurine and ethanol-induced conditioned taste aversion. Pharmacol Biochem Behav 44:263-266.

Boehm S, Harvey RJ, Von Holst A, Rohrer H, Betz H (1997) Glycine receptors in cultured chick sympathetic neurons are excitatory and trigger neurotransmitter release. J Physiol 504:683-694.

Boese SH, Wehner F, Kinne RHK (1996) Taurine permeation through swelling-activated anion conductance in rat IMCD cells in primary culture. Am J Physiol 271:F498-F507.

Bowser MT, Kennedy RT (2001) In vivo monitoring of amine neurotransmitters using microdialysis with on-line capillary electrophoresis. Electrophoresis 22:3668-3676.

Bres V, Hurbin A, Duvoid A, Orcel H, Moos FC, Rabie A, Hussy N (2000) Pharmacological characterization of volume-sensitive, taurine permeable anion channels in rat supraoptic glial cells. Br J Pharmacol 130: 1976-1982.

Brodie MS, Appel SB (1998) The effects of ethanol on dopaminergic neurons of the ventral tegmental area studied with intracellular recording in brain slices. Alcohol Clin Exp Res 22:236-244.

Brodie MS, Shefner SA, Dunwiddie TV (1990) Ethanol increases the firing rate of dopamine neurons of the rat ventral tegmental area in vitro. Brain Res 508:65-69.

Budygin EA, Phillips PE, Robinson DL, Kennedy AP, Gainetdinov RR, Wightman RM (2001) Effect of acute ethanol on striatal dopamine neurotransmission in ambulatory rats. J Pharmacol Exp Ther 297:27-34.

Bureau MH, Olsen RW (1991) Taurine acts on a subclass of $\mathrm{GABA}_{\mathrm{A}}$ receptors in mammalian brain in vitro. Eur J Pharmacol 207:9-16.

Chattipakorn SC, McMahon LL (2002) Pharmacological characterization of glycine-gated chloride currents recorded in rat hippocampal neurons. J Neurophysiol 87:1515-1525.

Collins CG, Topiwala SH (1974) The release of ${ }^{14} \mathrm{C}$ taurine from slices of rat cerebral cortex and spinal cord evoked by electrical stimulation and high potassium ion concentration. Br J Pharmacol 50:451P-452P.

Dahchour A, De Witte P (1999) Effect of repeated ethanol withdrawal on glutamate microdialysate in the hippocampus. Alcohol Clin Exp Res 23:1698-1703.

Dahchour A, De Witte P (2000a) Ethanol and amino acids in the central nervous system: assessment of the pharmacological actions of acamprosate. Prog Neurobiol 60:343-362.

Dahchour A, De Witte P (2000b) Taurine blocks the glutamate increase in the nucleus accumbens microdialysate of ethanol dependent rats. Pharmacol Biochem Behav 65:345-350.

Dahchour A, De Witte P (2003) Excitatory and inhibitory amino acid changes during repeated episodes of ethanol withdrawal: an in vivo microdialysis study. Eur J Pharmacol 459:171-178. 
Dahchour A, De Witte P, Bolo N, Nedelec JF, Muzet M, Durbin P, Macher J-P (1998) Central effects of acamprosate: part 1. Acamprosate blocks the glutamate increase in the nucleus accumbens microdialysate in ethanol withdrawn rats. Psychiat Res 82:107-114.

Dahchour A, Hoffman A, Deitrich R, De Witte P (2000) Effects of ethanol on extracellular amino acid levels in high and low alcohol sensitive rats: a microdialysis study. Alcohol Alcohol 35:548-553.

Dahchour A, Quertemont E, DeWitte P (1994) Acute ethanol increases taurine but neither glutamate nor GABA in the nucleus accumbens of male rats: a microdialysate study. Alcohol Alcohol 29:485-487.

Dahchour A, Quertemont E, DeWitte P (1996) Taurine increases in the nucleus accumbens microdialysate after acute ethanol administration to naive and chronically alcoholised rats. Brain Res 735:9-19.

Davison AN, Kaczmarek LK (1971) Taurine-a possible neurotransmitter? Nature (Lond.) 234:107-108.

Dawson R, Wallace DR (1992) Taurine content in tissues from aged Fischer 344 rats. Age 15:73-81.

De Witte P, Dahchour A, Quertemont E (1994) Acute and chronic alcohol injections increase taurine in the nucleus accumbens. Alcohol Alcohol (Suppl 2):229-233.

Del Olmo N, Bustamante J, Del Rio RM, Solis JM (2000) Taurine activates $\mathrm{GABA}(\mathrm{A})$ but not $\mathrm{GABA}(\mathrm{B})$ receptors in rat hippocampal CA1 area. Brain Res 864:298-307.

El-Ghundi M, George SR, Drago J, Fletcher PJ, Fan T, Nguyen T, Liu C, Sibley DR, Westphal H, O'Dowd BF (1998) Disruption of dopamine D1 receptor gene expression attenuates alcohol-seeking behavior. Eur J Pharmacol 353:149-158.

Fitzgerald LW, Nestler EJ (1995) Molecular and cellular adaptations in signal transduction pathways following ethanol exposure. Clin Neurosci $3: 165-173$.

Gonzales RA, Weiss F (1998) Suppression of ethanol-reinforced behavior by naltrexone is associated with attenuation of ethanol-induced increase in dialysate dopamine levels in nucleus accumbens. J Neurosci 18: 10663-10671.

Haas HL, Hösli L (1973) The depression of brain stem neurons by taurine and its interaction with strychnine and bicuculline. Brain Res 52:399_ 402

Han NL, Haddrill JL, Lynch JW (2001) Characterization of a glycine receptor domain that controls the binding and gating mechanisms of the $\beta$-amino acid agonist, taurine. J Neurochem 79:636-647.

Harris RA (1999) Ethanol actions on multiple ion channels: which are important? Alcohol Clin Exp Res 23:1563-1570.

Heidbreder C, De Witte P (1993) Ethanol differentially affects extracellular monoamines and GABA in the nucleus accumbens. Pharmacol Biochem Behav 46:477-481.

Hodge CW, Samson HH, Chappell AM (1997) Alcohol self-administration: further examination of the role of dopamine receptors in the nucleus accumbens. Alcohol Clin Exp Res 21:1083-1091.

Horikoshi T, Asanuma A, Yanagisawa K, Anzai K, Goto S (1988) Taurine and $\beta$-alanine act both on GABA and glycine receptors in Xenopus oocytes injected with mouse brain messenger RNA. Mol Brain Res 4:97-105.

Huxtable RJ (1989) Taurine in the central nervous system and the mammalian actions of taurine. Progress Neurobiol 32:471-533.

Huxtable RJ (1992) Physiological actions of taurine. Physiol Rev 72:101163.

Kaczmarek LK, Davison AN (1972) Uptake and release of taurine from rat brain slices. J Neurochem 19:2355-2362.

Kiianmaa K, Nurmi M, Nykanen I, Sinclair JD (1995) Effect of ethanol on extracellular dopamine in the nucleus accumbens of alcohol-preferring AA and alcohol-avoiding ANA rats. Pharmacol Biochem Behav 52:29_ 34.

Koob GF, Roberts AJ, Schulteis G, Parsons LH, Heyser CJ, Hyytia P, Merlo-Pich E, Weiss F (1998) Neurocircuitry targets in ethanol reward and dependence. Alcohol Clin Exp Res 22:3-9.

Lada MW, Kennedy RT (1996) Quantitative in vivo monitoring of primary amines in rat caudate nucleus using microdialysis coupled to flow gate interference with capillary electrophoresis-laser induced fluorescence detection. Anal Chem 68:2790-2797.

Lada MW, Vickroy TW, Kennedy RT (1998) Evidence for neuronal origin and metabotrobic receptor-mediated regulation of extracellular glutamate and aspartate in rat striatum in vivo following electrical stimulation of the prefrontal cortex. J Neurochem 70:617-625.

Lallemande F, Dahchour A, Ward RJ, De Witte P (2000) Does taurine play an osmolarity role during ethanol intoxication? Adv Exp Med Biol 483:203-212.

Lehmann A, Lazarewicz JW, Zeise M (1985) N-methylaspartate-evoked liberation of taurine and phosphoethanolamine in vivo: site of release. J Neurochem 45:1172-1177.

Liljequist R (1993) Interaction of taurine and related compounds with GABAergic neurones in the nucleus raphe dorsalis. Pharmacol Biochem Behav 44:107-112.

Lovinger DM, White G, Weight FF (1989) Ethanol inhibits NMDAactivated ion current in hippocampal neurons. Science (Wash. DC) 243:1721-1724.

Magnusson KR, Koerner JF, Larson AA, Smullin DH, Skilling SR, Beitz AJ (1991) NMDA-, kainate- and quisqualate-stimulated release of taurine from electrophysiologically monitored rat hippocampal slices. Brain Res 549:1-8.

Martin G, Siggins GR (2002) Electrophysiological evidence for expression of glycine receptors in freshly isolated neurons from nucleus accumbens. J Pharmacol Exp Ther 302:1135-1145.

Medina JH, De Robertis E (1984) Taurine modulation of the benzodiazepine- $\gamma$-aminobutyric acid receptor complex in brain membranes. J Neurochem 42:1212-1217.

Moghaddam B, Bolinao ML (1994) Biphasic effect of ethanol on extracellular accumulation of glutamate in the hippocampus and the nucleus accumbens. Neurosci Lett 178:99-102.

Mori M, Gahwiler BH, Gerber U (2002) $\beta$-alanine and taurine as endogenous agonists at glycine receptors in rat hippocampus in vitro. J Physiol 539:191-200

Nevo I, Hamon M (1995) Neurotransmitter and neuromodulatory mechanisms involved in alcohol abuse and alcoholism. Neurochem Int 26: 305-342.

Nurmi M, Sinclair JD, Kiianmaa K (1998) Dopamine release during ethanol drinking in AA rats. Alcohol Clin Exp Res 22:1628-1633.

Okamoto K, Kimura H, Sakai Y (1983) Taurine-induced increases of the Cl-conductance of cerebellar Purkinje cell dendrites in vitro. Brain Res 259:319-323.

Olive MF, Nannini MA, Ou CJ, Koenig HN, Hodge CW (2002) Effects of acute acamprosate and homotaurine on ethanol intake and ethanolstimulated mesolimbic dopamine release. Eur J Pharmacol 437:55-61.

Oja SS, Saransaari P (2000) Modulation of taurine release by glutamate receptors and nitric oxide. Prog Neurobiol 62:407-425.

Paxinos G, Watson C (1997) The Rat Brain in Stereotaxic Coordinate. Academic Press, New York.

Pettit HO, Justice JB Jr (1991) Procedures for microdialysis with smallbore HPLC, in Microdialysis in the Neurosciences (Robinson TE, Justice JB Jr, eds), p 117. Elsevier, New York.

Phillips TJ, Brown KJ, Burkhart-Kasch S, Wenger CD, Kelly MA, Rubinstein M, Grandy DK, Low MJ (1998) Alcohol preference and sensitivity are markedly reduced in mice lacking dopamine D2 receptors. Nat Neurosci 1:610-615.

Piepponen TP, Kiianmaa K, Ahtee L (2002) Effects of ethanol on the accumbal output of dopamine, GABA and glutamate in alcoholtolerant and alcohol-nontolerant rats. Pharmacol Biochem Behav 74: 21-30.

Pow DV, Sullivan R, Reye P, Hermanussen S (2002) Localization of taurine transporters, taurine and ${ }^{3} \mathrm{H}$-taurine accumulation in the rat retina, pituitary, and brain. Glia 37:153-168.

Proctor WR, Poelchen W, Bowers BJ, Wehner JM, Messing RO, Dunwiddie TV (2003) Ethanol differentially enhances hippocampal GABA A receptor-mediated responses in protein kinase $\mathrm{C}$ gamma (PKC 
gamma) and PKC epsilon null mice. J Pharmacol Exp Ther 305:264270.

Quertemont E, Devitgh A, DeWitte P (2001) Ethanol-induced brain extracellular taurine release: an osmoregulatory mechanism. Alcohol Alcohol 36:476-485.

Quertemont E, Devitgh A, DeWitte P (2003) Systemic osmotic manipulations modulate ethanol-induced taurine release: a brain microdialysis study. Alcohol 29:11-19.

Quertemont E, Goffaux V, Vlaminck AM, Wolf C, DeWitte P (1998) Oral taurine supplementation modulated ethanol-conditioned stimulus preference. Alcohol 16:201-206.

Quertemont E, Lallemand F, Colombo G, De Witte P (2000) Taurine and ethanol preference: a microdialysis study using Sardinian alcoholpreferring and non-preferring rats. Eur Neuropsychopharmacol 10:377383.

Quertemont E, Linotte S, De Witte P (2002) Differential taurine responsiveness to ethanol in high- and low-alcohol sensitive rats: a brain microdialysis study. Eur J Pharmacol 444:143-150.

Quinn MR, Harris CL (1995) Taurine allosterically inhibits binding of $\left[{ }^{35} \mathrm{~S}\right]-t$-butylbicyclo-phosphorothionate (TBPS) to rat brain synaptic membranes. Neuropharmacology 34:1607-1613.

Sánchez-Olea R, Pasantes-Morales H (1990) Chloride dependence of the $\mathrm{K}^{+}$-stimulated release of taurine from synaptosomes. Neurochem Res 15:535-540.

Saransaari P, Oja SS (2000) Modulation of taurine release by metabotropic receptors in the developing hippocampus. Adv Exp Med Biol 483:257-264

Schmieden V, Kuhse J, Betz H (1992) Agonist pharmacology of neonatal and adult glycine receptor $\alpha$ subunits: identification of amino acid residues involved in taurine activation. EMBO J 11:2025-2032.

Schousboe A, Sánchez-Olea R, Pasantes-Morales H (1990) Depolarization induced neuronal release of taurine to synaptic transmission: comparison with GABA and glutamate. Prog Clin Biol Res 351:287-297.
Sergeeva OA, Haas HL (2001) Expression and function of glycine receptors in striatal cholinergic interneurons from rat and mouse. Neuroscience 104:1043-1055.

Shain W, Martin DL (1990) Uptake and release of taurine-an overview. Prog Clin Biol Res 351:234-252.

Smith A, Kennedy RT, Watson CJ, Peris J (2003a) Ethanol-induced taurine efflux: Low dose effects and high temporal resolution, in Taurine 5 (Lombardini JB, Schaffer SW, Azuma J eds), pp 485-492. Plenum Press, New York.

Smith A, Shou M, Watson CJ, Shackman J, Kennedy RT, Peris J (2003b) Calcium dependency of biphasic ethanol-induced taurine efflux in the nucleus accumbens (abstract). Soc Neurosci 29:108.10.

Smith KE, Borden LA, Wang CH, Hartig PR, Branchek TA, Weinshank RL (1992) Cloning and expression of a high affinity taurine transporter from rat brain. Mol Pharmacol 42:563-569.

Timmerman W, Westerink BHC (1997) Brain microdialysis of GABA and glutamate: What does it signify? Synapse 27:242-261.

Tsai G (1998) Glutamatergic neurotransmission in alcoholism. J Biomed Sci 5:309-320.

Wright CE, Talla HH, Lin YY, Gaull GE (1986) Taurine: biological update. Annu Rev Biochem 55:427-453.

Ye G, Tse AC, Yung W (1997) Taurine inhibits rat substantia nigra par reticulata neurons by activation of GABA-and glycine-linked chloride conductance. Brain Res 749:175-179.

Yim HJ, Schallert T, Randall PK, Gonzales RA (1998) Comparison of local and systemic ethanol effects on extracellular dopamine concentration in rat nucleus accumbens by microdialysis. Alcohol Clin Exp Res 22:367-374.

Yoshimoto K, McBride WJ, Lumeng L, Li T-K (1991) Alcohol stimulates the release of dopamine and serotonin in the nucleus accumbens. Alcohol Clin Exp Res 9:17-22.

Yoshimoto K, McBride WJ, Lumeng L, Li T-K (1992) Ethanol enhances the release of dopamine and serotonin in the nucleus accumbens of HAD and LAD lines of rats. Alcohol Clin Exp Res 16:781-785. 